\title{
The interaction of GSSG modified magnetic nanoparticles with SPC-A1 cells in vitro
}

\author{
MA YongJie, YAN ZhuBing, XU Hong \& GU HongChen* \\ Nano Biomedical Research Center, School of Biomedical Engineering, Shanghai Jiao Tong University, Shanghai 200030, China
}

Received August 8, 2011; accepted February 8, 2012; published online May 6, 2012

\begin{abstract}
Magnetic nanoparticles (MNPs) are promising materials for various biomedical applications, including magnetic resonance imaging, stem cell tracking, gene/drug delivery, and cancer treatment. To increase the effectiveness of MNPs, high capture efficiency and controlled uptake of the particles by cells is required. In this paper we report the cytotoxicity and cellular uptake into SPC-A1 cells of oxidized glutathione (GSSG)-modified MNPs ( GSSG@ $@ \mathrm{Fe}_{3} \mathrm{O}_{4}$ ). Experimental findings indicated that GSSG@ $\mathrm{Fe}_{3} \mathrm{O}_{4}$ were biocompatible, and could be efficiently taken up by SPC-A1 cells (up to 160 pg iron per cell). The internalized GSSG@ $\mathrm{Fe}_{3} \mathrm{O}_{4}$ was retained in the cell cytoplasm for 6 generations. The uptake of GSSG@ $\mathrm{Fe}_{3} \mathrm{O}_{4}$ into SPC-A1 cells was energy-, concentration- and time-dependent. Pinocytosis may be involved in the internalization process of GSSG@ $\mathrm{Fe}_{3} \mathrm{O}_{4}$ into SPC-A1 cells, but this mechanism remains to be elucidated. The controlled and efficient localization of GSSG@ $\mathrm{Fe}_{3} \mathrm{O}_{4}$ into the cytosol and long intracellular retention provides theoretical and experimental insight into the biomedical applications for these molecules.
\end{abstract}

magnetic nanoparticles, uptake, glutathione, GSSG, SPC-A1

Citation: $\quad$ Ma Y J, Yan Z B, Xu H, et al. The interaction of GSSG modified magnetic nanoparticles with SPC-A1 cells in vitro. Chin Sci Bull, 2012, 57: 3525-3531, doi: $10.1007 / \mathrm{s} 11434-012-5185-0$

Magnetic nanoparticles (MNPs) can be used in a wide variety of biomedical applications, ranging from cell labeling, magnetic resonance imaging, and gene/drug delivery for cancer treatment [1-9]. The uptake of MNPs by living cells very much depends on the MNP coating. Surface modification can improve the biocompatibility and enhance cell uptake of MNPs [10-15]. MNPs coated with dextran, or its derivatives, have been frequently used in the context of labeling cells with a magnetic tag [16]. However, cell accumulation of these particles is usually low in non-phagocytic cells, culminating in a low MR detection sensitivity. The application of MNPs is affected by the net amount that are internalized, and those that remain within the cells after initial endocytosis, followed by exocytosis and intracellular degradation [13]. The cellular uptake of MNPs, especially their intracellular retention, is clearly crucial to the above applications. We therefore synthesized GSSG@ $\mathrm{Fe}_{3} \mathrm{O}_{4}$, since

*Corresponding author (email: hcgu@ sjtu.edu.cn) glutathione is found in all cells in the body making it a very compatible target for MNP technology. These MNPs were then evaluated for their cytotoxicity, cellular uptake and intracellular retention into SPC-A1 cells.

Most of the promising MNP applications, especially MRI and stem cell tracking, require well-defined and controllable interactions between the MNPs and living cells $[1-5,8]$. Furthermore, cellular uptake and intracellular pathways are dependent on the MNPs and cell type $[9,13,16]$, so it is crucial to elucidate the uptake kinetics and cellular internalization pathways for GSSG@ $\mathrm{Fe}_{3} \mathrm{O}_{4}$. This study provides theoretical and experimental insight into the biomedical applications of GSSG@ $@ \mathrm{Fe}_{3} \mathrm{O}_{4}$.

\section{Materials and methods}

\subsection{Materials and equipment}

(1) Materials. $\mathrm{FeCl}_{3} \cdot 6 \mathrm{H}_{2} \mathrm{O}$ (Analytical Reagent, AR), 
$\mathrm{FeSO}_{4} \cdot 7 \mathrm{H}_{2} \mathrm{O}$ (AR), GSSG (AR), nuclear fast red, Prussian blue, glutaraldehyde solution, dimethyl sulfoxide (DMSO), MTT solution and LDH cytotoxicity assay kit were all purchased from Sigma Aldrich (Shanghai, China). Colchicine and cytochalasin B were from Sino-American Biotec (Shanghai, China). SPC-A1 (human lung adenocarcinoma cell line) was purchased from the Cell Bank of the Chinese Academy of Sciences. DMEM culture medium (high glucose) and fetal calf serum were obtained from Hyclone (Shanghai, China). All other reagents were obtained from Shanghai Reagent Company.

(2) Equipment. The equipment used in this study included transmission electron microscopes (TEM, Philips CM-120 for the observation of MNPs and Philips Tecnai 20S-TWIN for the observation of cell samples), Fourier transform infrared spectrometer (FTIR, Bruker EQUINOX 55FTIR), Multilabel Counter (Victor-3, Perkin Elmer, USA) and an inductively coupled plasma optical emission spectrometer (ICP-OES, ICAP-6300, Thermo Fisher, USA).

\subsection{Methods}

(1) Preparation of GSSG @ $\mathrm{Fe}_{3} \mathrm{O}_{4}$. MNPs were prepared by co-precipitation of ferric and ferrous salts in an alkaline solution [17]. In brief, $\mathrm{FeCl}_{3} \cdot 6 \mathrm{H}_{2} \mathrm{O}(24.3 \mathrm{~g})$ and $\mathrm{FeSO}_{4} \cdot 7 \mathrm{H}_{2} \mathrm{O}$ $(16.7 \mathrm{~g})$ were first dissolved in $200 \mathrm{~mL}$ deionized water under a blanket of nitrogen gas and heated to $75^{\circ} \mathrm{C}$. Then ammonia solution $(45 \mathrm{~mL}, 25 \%(\mathrm{v} / \mathrm{v}))$ was added dropwise to the mixture with vigorous stirring. After stirring for $30 \mathrm{~min}$, the temperature was raised to $85^{\circ} \mathrm{C}$ and GSSG $(0.2 \mathrm{~g})$ was added to the mixture. After reacting for $1 \mathrm{~h}$, the mixture was cooled down to ambient temperature. The product was retrieved using a magnet, washed 5 times with deionized water and finally dispersed in water.

(2) Characterization of $\mathrm{GSSG} @ \mathrm{Fe}_{3} \mathrm{O}_{4}$ nanoparticles. The morphology and size of the particles were observed and analyzed by TEM. To do this, the particle suspension was directly deposited onto a carbon-coated copper grid and air-dried at room temperature. The particle size and size distribution were calculated using an image analysis software of Image $\mathbf{J}$ by measuring the diameter of at least 300 particles. The obtained particles were dissolved in deionized water and analyzed by FTIR.

(3) Cytotoxic evaluation of GSSG@ $\mathrm{Fe}_{3} \mathrm{O}_{4}$. SPC-A1 cells were cultured in DMEM medium, supplemented with $10 \%$ fetal calf serum at $37^{\circ} \mathrm{C}$ in a $95: 5 \mathrm{air} / \mathrm{CO}_{2}$ water-saturated atmosphere. Cell viability was investigated with MTT and LDH assays. For MTT assay, cells were seeded in 96-well plates $\left(1 \times 10^{5}\right.$ cells/well $)$ and incubated with culture medium containing GSSG@ $@ \mathrm{Fe}_{3} \mathrm{O}_{4}$ at iron concentrations of $0.6,1.0$ or $1.5 \mathrm{mg} / \mathrm{mL}$ for different periods of time $(6,12,24$ or $48 \mathrm{~h})$. After incubation, $20 \mu \mathrm{L}$ of MTT solution $(5 \mathrm{mg} / \mathrm{mL}$ in PBS) was added to each well and incubated for $4 \mathrm{~h}$. Then, the MTT containing medium was removed and $150 \mu \mathrm{L}$ DMSO was added to dissolve the formazan crystals pro- duced from the reduction of MTT by viable cells. The optical density was measured at $570 \mathrm{~nm}$ using a Multilabel Counter. The cell viability was calculated using the following equation: cell viability $=\mathrm{OD}_{\text {experiment }} / \mathrm{OD}_{\text {control }} \times 100 \%$. For the LDH assay, after co-culturing with GSSG $@ \mathrm{Fe}_{3} \mathrm{O}_{4}(0.6,1.0$ or $1.5 \mathrm{mg} \mathrm{Fe} / \mathrm{mL}$ ) for 24,48 or $72 \mathrm{~h}$, the supernatant was analyzed with a LDH cytotoxicity assay kit according to the manufacturer's protocol. SPC-A1 cells incubated with nanoparticle-free medium served as controls ( $100 \%$ cell viability).

(4) Intracellular retention of GSSG $@ \mathrm{Fe}_{3} \mathrm{O}_{4}$. The intracellular retention of GSSG@ $\mathrm{Fe}_{3} \mathrm{O}_{4}$ was evaluated by TEM observation. SPC-A1 cells were washed twice after a $24 \mathrm{~h}$ incubation period in culture medium containing $1.0 \mathrm{mg} / \mathrm{mL}$ GSSG@ $\mathrm{Fe}_{3} \mathrm{O}_{4}$, and cultured in fresh medium up to the 6th subpassage. Culture medium was changed every third day. After incubation, the culture medium was removed. The adhered cells of the 2nd, 4th or 6th generations were washed three times with PBS and harvested by trypsinization. The cells were centrifuged and redispersed into $4 \%(\mathrm{w} / \mathrm{v})$ glutaraldehyde and processed for analysis by TEM using previously published methods [18].

(5) Uptake kinetics of GSSG@ $@ \mathrm{Fe}_{3} \mathrm{O}_{4}$ by SPC-A1 cells. To evaluate the effects of temperature on cellular uptake, SPC-A1 cells were incubated with culture medium containing $0.2 \mathrm{mg} / \mathrm{mL} \mathrm{GSSG} @ \mathrm{Fe}_{3} \mathrm{O}_{4}$ at $4^{\circ} \mathrm{C}$ for $24 \mathrm{~h}$, or at $37^{\circ} \mathrm{C}$ for $1 \mathrm{~h}$. After incubation, the culture medium was removed. The adhered cells were washed three times with PBS, harvested by trypsinization, fixed and processed for TEM analysis.

To evaluate the effects of time and dose on cellular uptake, intracellular iron uptake was quantitatively analyzed using ICP-OES and qualitatively analyzed by Prussian blue iron stain assays. For quantitative analysis, SPC-A1 cells were incubated with a culture medium containing GSSG@ $\mathrm{Fe}_{3} \mathrm{O}_{4}$ at the concentrations of $0.1,0.4,0.7$ or $1.0 \mathrm{mg} \mathrm{Fe} / \mathrm{mL}$ at $37^{\circ} \mathrm{C}$ for different periods of time $(3,6,12,24,48$ or $72 \mathrm{~h})$. After incubation, the culture medium was removed. The adhered cells were washed, harvested, and digested with aqua regia, and then diluted to $10 \mathrm{~mL}$. The iron content in cells was determined by ICP-OES. The iron content was expressed in picogram (pg) of Fe per cell.

For qualitative analysis, SPC-A1 cells were incubated with GSSG@ $\mathrm{Fe}_{3} \mathrm{O}_{4}$ at the same iron concentration $(0.4 \mathrm{mg} / \mathrm{mL})$ for $6 \mathrm{~h}, 24 \mathrm{~h}$ or co-cultured for the same time period $(24 \mathrm{~h})$ at an iron concentration of 0.1 or $1.0 \mathrm{mg} / \mathrm{mL}$. After incubation, adhered cells were washed and observed by Prussian blue staining. For Prussian blue staining, the collected cells were fixed with methanol for $5 \mathrm{~min}$, then acetone for $1 \mathrm{~min}$, under $-20^{\circ} \mathrm{C}$ and then air dried for 15 min. Slides were soaked in PBS for $5 \mathrm{~min}$, and then incubated with $10 \%$ Prussian blue $\left[\mathrm{K}_{4} \mathrm{Fe}(\mathrm{CN})_{6} \cdot 3 \mathrm{H}_{2} \mathrm{O}\right]$ for $5 \mathrm{~min}$. Subsequently, slides were further incubated with a mixture of $10 \%$ Prussian blue and $20 \% \mathrm{HCl}(1: 1)$ for $30 \mathrm{~min}$, water for $10 \mathrm{~min}$ and finally nuclear fast red (Sigma Aldrich) for $10 \mathrm{~min}$. Slides were then washed with water, 70\%, 80\%, 100\% ethanol (twice) 
and subsequently xylene. The slides were coverslipped with Vitro Clud coverslipping medium in preparation for microscopy.

(6) Internalization pathway of GSSG@ $\mathrm{Fe}_{3} \mathrm{O}_{4}$ in SPC-A1 cells. To investigate the possible pathway of cellular internalization of GSSG@ $\mathrm{Fe}_{3} \mathrm{O}_{4}$, SPC-A1 cells were pretreated with $50 \mu \mathrm{g} / \mathrm{mL}$ colchicine (an inhibitor of pinocytosis) or 50 $\mu \mathrm{g} / \mathrm{mL}$ cytochalasin B (an inhibitor of phagocytosis) $[19,20]$ for $4 \mathrm{~h}$ at $37^{\circ} \mathrm{C}$. After incubation, the pretreatment solution was removed and the cells were washed with PBS. Cells were then co-cultured with $0.2 \mathrm{mg} / \mathrm{mL}$ GSSG@ $\mathrm{Fe}_{3} \mathrm{O}_{4}$ for $24 \mathrm{~h}$. The intracellular iron was measured by ICP-OES and the cellular uptake of GSSG@ $@ \mathrm{Fe}_{3} \mathrm{O}_{4}$ was observed by TEM. Statistical analyses were performed using SPSS 13.0 software. The results were presented as the mean $\pm \mathrm{SD}$ and compared using Student's $t$-test. $P<0.05$ was considered significant. To further investigate the uptake pathway of GSSG@$\mathrm{Fe}_{3} \mathrm{O}_{4}$, TEM assays were performed. SPC-A1 cells were incubated in medium containing $1.0 \mathrm{mg} / \mathrm{mL} \mathrm{GSSG@} \mathrm{Fe}_{3} \mathrm{O}_{4}$ for 1,3 or $6 \mathrm{~h}$. After incubation, the cells were washed, collected, fixed and processed for analysis by TEM.

\section{Results and discussion}

\subsection{Characterization of GSSG@ $\mathrm{Fe}_{3} \mathrm{O}_{4}$ nanoparticles}

GSSG@ $\mathrm{Fe}_{3} \mathrm{O}_{4}$ were well dispersed and the visualized diameters were roughly 7-15 nm (Figure 1). FTIR spectra of GSSG@ $\mathrm{Fe}_{3} \mathrm{O}_{4}$ and uncoated MNPs are shown in Figure 1. The FTIR spectra of GSSG@ $\mathrm{Fe}_{3} \mathrm{O}_{4}$ exhibited characteristic absorption bands of an amido bond at $1640 \mathrm{~cm}^{-1}$ due to the $\mathrm{V}_{\mathrm{C}=\mathrm{O}}$ stretching vibration, which meant when GSSG was binding to iron ions found on the MNPs. The amido bonds were not involved in the reaction and the carboxyl groups of GSSG were probably chelated on the surface of MNPs. The
$\delta_{\mathrm{NH}}$ bending vibration at $1550 \mathrm{~cm}^{-1}$ and $\mathrm{V}_{\mathrm{CN}}$ stretching vibration at $1405 \mathrm{~cm}^{-1}$ were observed in GSSG@ $\mathrm{Fe}_{3} \mathrm{O}_{4}$, but not observed in naked MNPs, indicating that MNPs were successfully coated with GSSG.

\subsection{Cytotoxic evaluation of GSSG@ $\mathrm{Fe}_{3} \mathrm{O}_{4}$}

As shown in Figure 2(a), after incubation with GSSG@ $\mathrm{Fe}_{3} \mathrm{O}_{4}$, cell viability was similar to the control cells cultured with GSSG@ $\mathrm{Fe}_{3} \mathrm{O}_{4}$-free medium. Even when cells were co-cultured with medium containing GSSG@ $\mathrm{Fe}_{3} \mathrm{O}_{4}$ at 1.5 $\mathrm{mg} / \mathrm{mL}$ for $48 \mathrm{~h}$, cell viability was still more than $90 \%$ (Figure 2(a)). LDH cytotoxicity assays were performed after co-culture with different concentrations of GSSG@ $\mathrm{Fe}_{3} \mathrm{O}_{4}$ for different periods of time. LDH release from SPC-A1 cells was not obviously different compared with the control (Figure 2(b)). These results demonstrated that GSSG@ $\mathrm{Fe}_{3} \mathrm{O}_{4}$ did not cause severe cytotoxicity under the current conditions.

Unmodified MNPs have been shown to cause cytotoxicity above a certain concentration [10]. This cytotoxicity has been shown to increase in a concentration dependent manner [21]. Although the MNPs were coated with biocompatible molecules, such as dextran, to reduce cytotoxicity [22], the reported concentrations of MNPs in culture medium shown to cause cytotoxicity were seldom more than $1 \mathrm{mg} / \mathrm{mL}$.

\subsection{Intracellular retention of GSSG@ $\mathrm{Fe}_{3} \mathrm{O}_{4}$}

After incubation with culture medium containing $1.0 \mathrm{mg} / \mathrm{mL}$ GSSG@ $\mathrm{Fe}_{3} \mathrm{O}_{4}$ for $24 \mathrm{~h}, \mathrm{SPC}-\mathrm{A} 1$ cells were cultured in culture medium free of GSSG@ $\mathrm{Fe}_{3} \mathrm{O}_{4}$ for up to the six generations. As shown in Figure 3(a), many nanoparticles in the cytoplasm of the 2 nd generation SPC-A1 cells could be observed using TEM. Intracellular nanoparticles reduced in
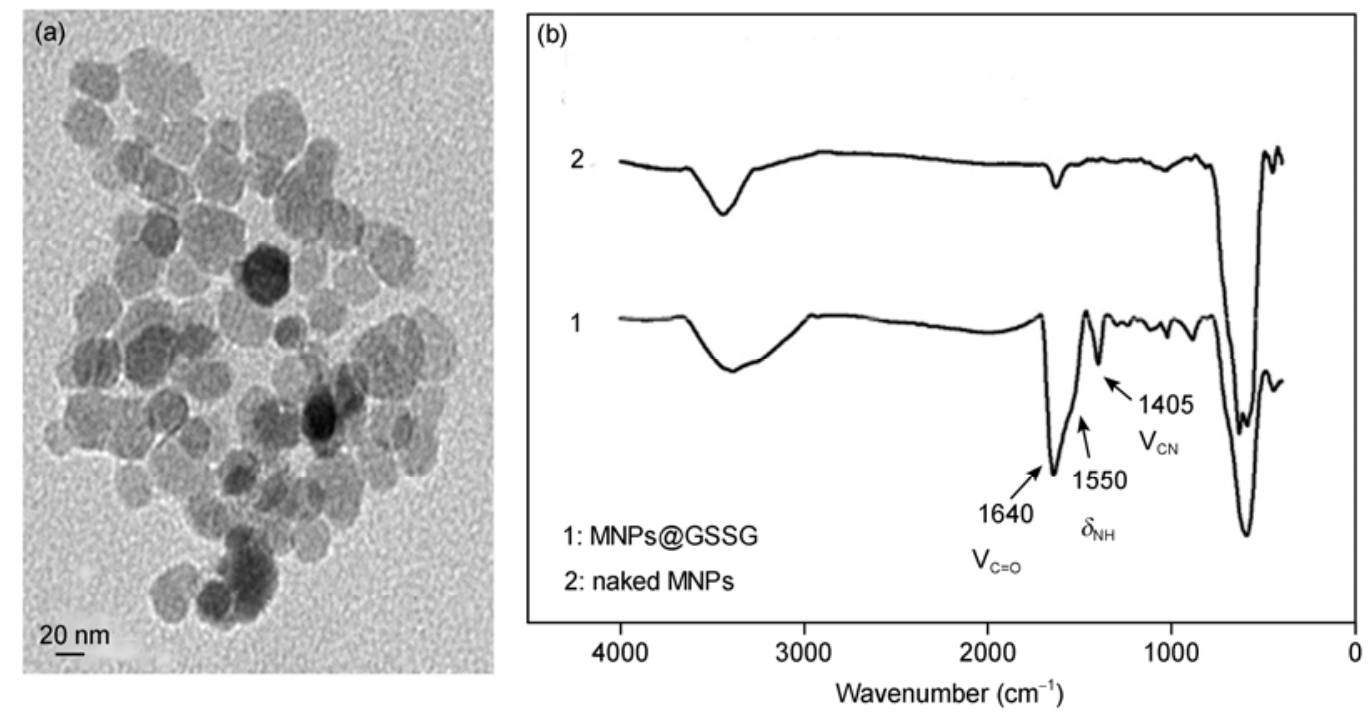

Figure 1 (a) TEM image of GSSG@ $\mathrm{Fe}_{3} \mathrm{O}_{4}$ (scale bar=20 nm) and (b) IR spectra of GSSG@ $\mathrm{Fe}_{3} \mathrm{O}_{4}(1)$ and uncoated MNPs (2). 

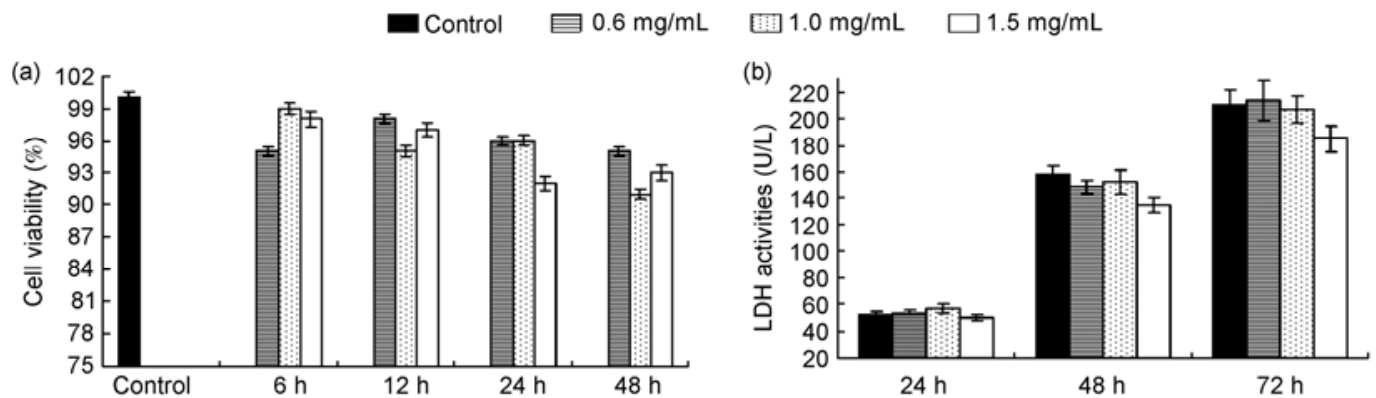

Figure 2 Cytotoxic evaluation of GSSG@ $\mathrm{Fe}_{3} \mathrm{O}_{4}$. SPC-A1 cells were incubated with culture medium containing GSSG@ $\mathrm{Fe}_{3} \mathrm{O}_{4}$ at various iron concentrations for different periods of time. Subsequently, cell survival and LDH activities were determined by MTT (a) and LDH assays (b) (mean \pm SD, $n=3$ ). SPC-A1 cells incubated with GSSG@ $\mathrm{Fe}_{3} \mathrm{O}_{4}$-free medium served as controls (blank, 100\% cell viability).

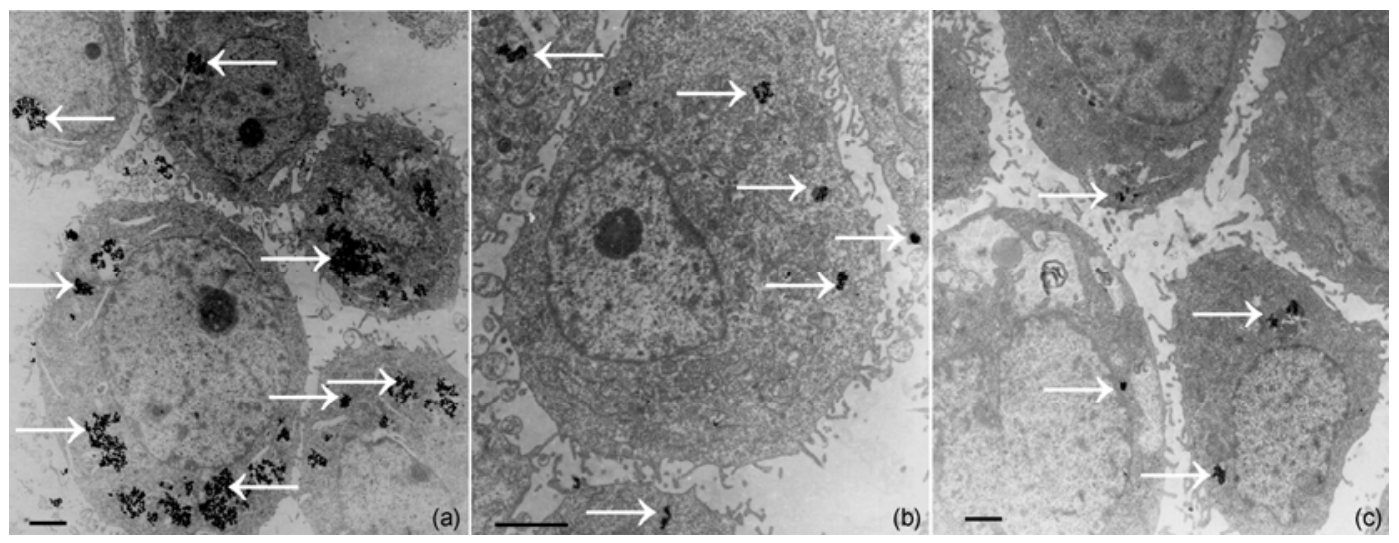

Figure 3 TEM images of sub-cultured cells after co-culture with GSSG@ $\mathrm{Fe}_{3} \mathrm{O}_{4}$. The 2nd (a), the 4th (b) and the 6th (c) generation of SPC-A1 cells after co-culture with GSSG@ $\mathrm{Fe}_{3} \mathrm{O}_{4}$. Arrows show GSSG@ $\mathrm{Fe}_{3} \mathrm{O}_{4}$ located in the cytoplasm. Scale bar=1 $\mu \mathrm{m}$.

number from generation to generation, but remained visible until the 6th subpassage (Figure 3(c)). After the 6th generation nanoparticles were hardly observed in the cytoplasm as GSSG@ $\mathrm{Fe}_{3} \mathrm{O}_{4}$ may be distributed to subpassaged cells via mitosis and eliminated via exocytosis.

Cytotoxicity and intracellular retention assays demonstrated that at a certain concentration range $(0-1.5 \mathrm{mg} / \mathrm{mL})$, GSSG@ $\mathrm{Fe}_{3} \mathrm{O}_{4}$ had no obvious cytotoxic effects on SPC-A1 cells, and that internalized GSSG@ $\mathrm{Fe}_{3} \mathrm{O}_{4}$ could remain in SPC-A1 cells following several generations. These results imply the potential applied value of GSSG@ $\mathrm{Fe}_{3} \mathrm{O}_{4}$ to cell tracking, MRI and intracellular hyperthermia.

\subsection{Uptake kinetics of GSSG@ $\mathrm{Fe}_{3} \mathrm{O}_{4}$ into SPC-A1 cells}

GSSG@ $\mathrm{Fe}_{3} \mathrm{O}_{4}$ absorbed to the cell membrane after co-culture with SPC-A1 cells at $4^{\circ} \mathrm{C}$ for $1 \mathrm{~h}$. After culture for $24 \mathrm{~h}$, there were no nanoparticles observed in the cytoplasm (Figure 4(a)). When SPC-A1 cells were co-cultured with GSSG@ $\mathrm{Fe}_{3} \mathrm{O}_{4}$ at $37^{\circ} \mathrm{C}$ for $1 \mathrm{~h}$, nanoparticles were observed in the cytoplasm (Figure 4(b)). As endocytosis is inhibited at low temperatures, these findings indicate that the endocytosis of GSSG@ $\mathrm{Fe}_{3} \mathrm{O}_{4}$ was an energy-dependent and active process [23].
Both the results of iron content measurement assays and Prussian blue iron stain assays showed intracellular iron content was increased in a time and concentration dependent manner in SPC-A1 cells (Figure 5), which is in accordance with previous reports [12,18,24]. When co-cultured for $48 \mathrm{~h}$ at $1.0 \mathrm{mg} / \mathrm{mL}$ of $\mathrm{GSSG} @ \mathrm{Fe}_{3} \mathrm{O}_{4}$, the iron content reached a plateau of $160 \mathrm{pg}$ iron per cell (Figure 5A), suggesting the uptake of GSSG@ $\mathrm{Fe}_{3} \mathrm{O}_{4}$ was a saturable process [23].

Cell labeling with MNPs is an increasingly common method for in vitro cell separation as well as for in vivo imaging. Magnetic cell labeling also raises very promising developments for therapy by allowing magnetic intracellular hyperthermia. All these applications require that cells consistently and efficiently capture MNPs [21,23]. Our results demonstrated that the uptake of GSSG@ $\mathrm{Fe}_{3} \mathrm{O}_{4}$ by SPC-A1 cells was efficient and occurred in a concentration and timedependent manner, which is crucial for their use in the above-mentioned biomedical applications.

\subsection{Internalization pathway of GSSG@ $\mathrm{Fe}_{3} \mathrm{O}_{4}$ in $\mathrm{SPC}$ - A1 cells}

Historically, endocytic machinery has been classified into 


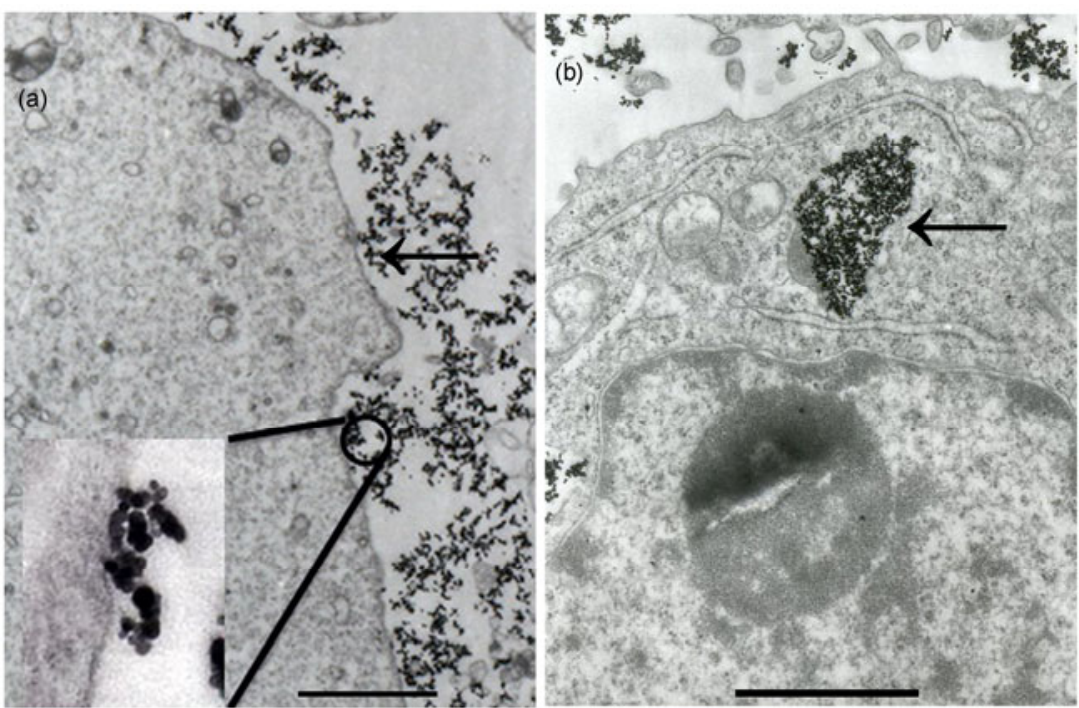

Figure 4 Temperature-dependent uptake of GSSG@ $\mathrm{Fe}_{3} \mathrm{O}_{4}$ by SPC-A1 cells. (a) Co-cultured SPC-A1 cells with $0.2 \mathrm{mg} / \mathrm{mL} \mathrm{GSSG} @ \mathrm{Fe}_{3} \mathrm{O}_{4}$ at $4{ }^{\circ} \mathrm{C}$ for $24 \mathrm{~h}$; (b) co-cultured SPC-A1 cells with $0.2 \mathrm{mg} / \mathrm{mL} \mathrm{GSSG} @ \mathrm{Fe}_{3} \mathrm{O}_{4}$ at $37^{\circ} \mathrm{C}$ for $1 \mathrm{~h}$. Scale bar $=1 \mu \mathrm{m}$.
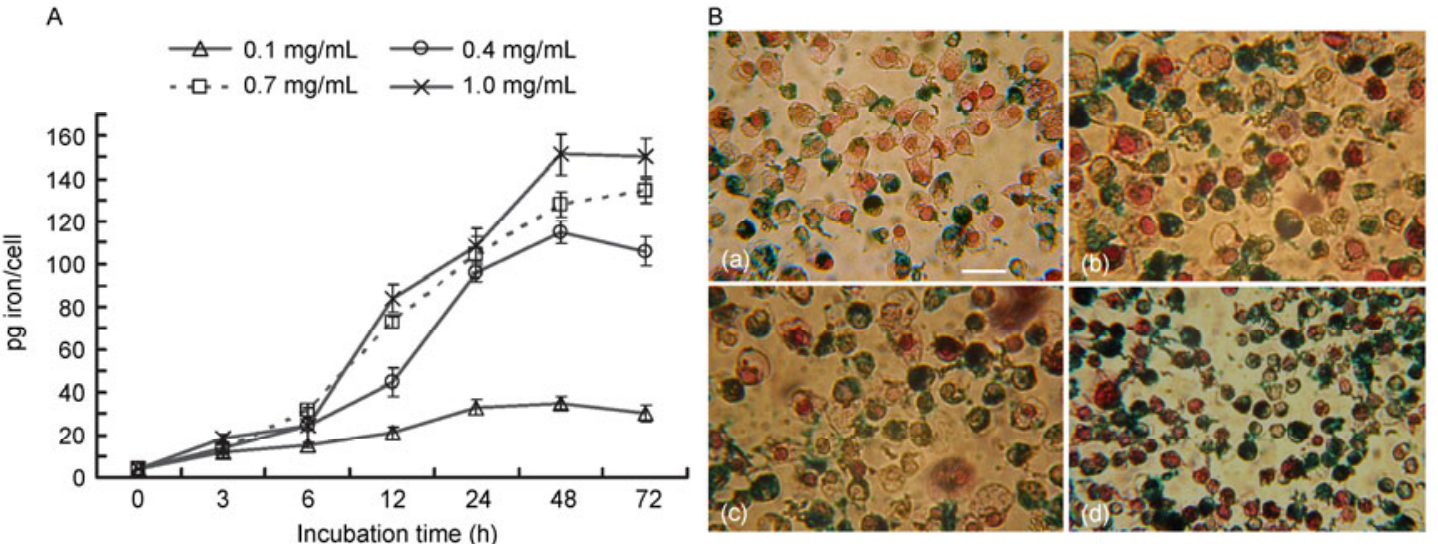

Figure 5 Time and concentration-dependent uptake of GSSG@ $\mathrm{Fe}_{3} \mathrm{O}_{4}$ by SPC-A1 cells. A. Quantitative analysis of intracellular iron uptake by ICP-OES. Co-cultured SPC-A1 cells with GSSG $@ \mathrm{Fe}_{3} \mathrm{O}_{4}$ at an iron concentration of $0.1,0.4,0.7$ or $1.0 \mathrm{mg} / \mathrm{mL}$ for different periods of time $(3,6,12,24,48$ or $72 \mathrm{~h}$ ), respectively. B. Qualitative analysis of iron uptake by Prussian blue iron stain essays (200×). Co-cultured SPC-A1 cells with GSSG@ $\mathrm{Fe}_{3} \mathrm{O}_{4}$ at different iron concentration for different time periods: (a) $0.4 \mathrm{mg} / \mathrm{mL}$ for $6 \mathrm{~h}$; (b) $0.4 \mathrm{mg} / \mathrm{mL}$ for $24 \mathrm{~h}$; (c) $0.1 \mathrm{mg} / \mathrm{mL}$ for $24 \mathrm{~h}$; (d) $1.0 \mathrm{mg} / \mathrm{mL}$ for $24 \mathrm{~h}$. Scale bar=50 $\mu \mathrm{m}$.

phagocytotic and pinocytotic [25]. Specifically, the pinocytotic pathway and phagocytotic pathway are inhibited by colchicine and cytochalasin B pretreatments, respectively $[19,20]$. We examined the impact of these inhibitors on these endocytotic pathways and noted the cellular uptake. The results are presented in Figure 6.

As shown in Figure 6, the amount of iron in SPC-A1 cells $(18.7 \pm 1.9 \mathrm{pg})$ was apparently reduced compared with the control $(82.6 \pm 5 \mathrm{pg})$ when pretreated with colchicine $(P<0.05)$, but this reduction did not occur with the treatment of cytochalasin B $(69.3 \pm 6.5 \mathrm{pg})$. These observations were in agreement with TEM observations (Figure 6B). Internalized GSSG@ $\mathrm{Fe}_{3} \mathrm{O}_{4}$ in the cytoplasm of SPC-A1 cells was greater in cells treated with cytochalasin B compared with colchicine. Colchicine, known as a functional inhibitor of mi- crotubule assembly that causes microtubule disruption, prevented nanoparticle uptake by inhibiting the pinocytotic pathway. These results suggest that pinocytosis appears to be the internalization pathway for $\mathrm{GSSG} @ \mathrm{Fe}_{3} \mathrm{O}_{4}$ in SPC-A1 cells.

TEM was then used to visualize the uptake process of GSSG $@ \mathrm{Fe}_{3} \mathrm{O}_{4}$ and the intracellular compartmentalization in SPC-A1 cells. After co-culture of the SPC-A1 cells with GSSG@ $\mathrm{Fe}_{3} \mathrm{O}_{4}$, the uptake process of nanoparticles from coated pits (Figure 7(a), black arrows) to endosomes (Figure 7(a), white arrows) and then lysosomes (Figure 7(c),(d)) was observed. We believe Figure 7(b) depicts the amalgamation process of endosomes (white arrow) and lysosomes (black arrow).

Previous reports $[12,23,26]$ and inhibition assays lead us 
A

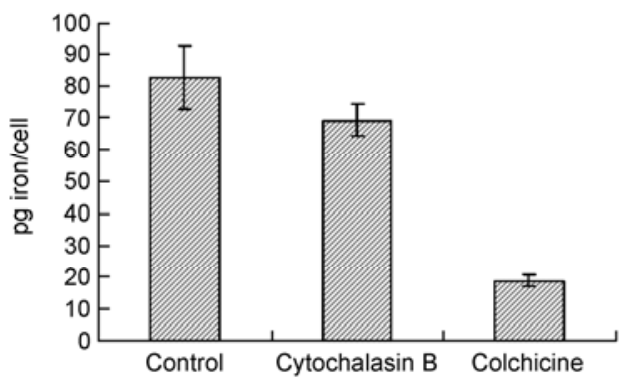

B

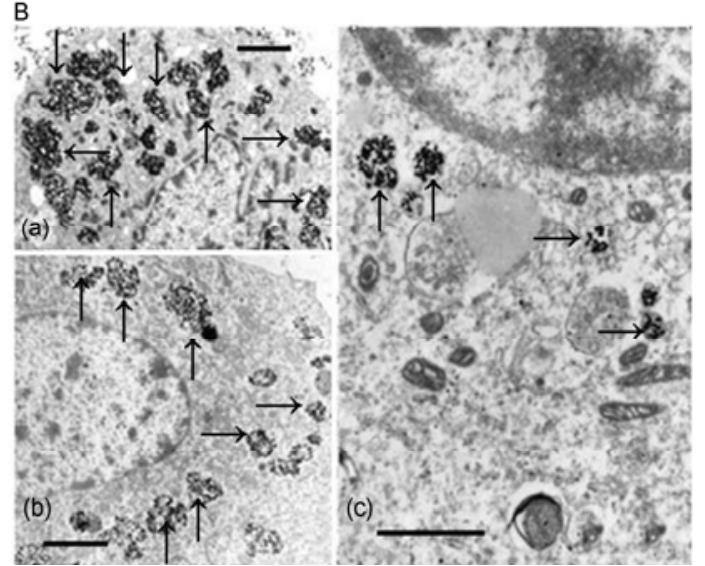

Figure 6 The effects of inhibitors on iron uptake. A, Iron uptake after cells were treated with inhibitors was determined by ICP-OES assays (mean \pm SD, $n=3$ ); B, TEM images of GSSG @ $\mathrm{Fe}_{3} \mathrm{O}_{4}$ uptake by SPC-A1 cells after treatment with inhibitors ((a) control; (b) cytochalasin B; (c) colchicine). Scale bar=1 $\mu \mathrm{m}$. SPC-A1 cells incubated with inhibitor-free medium served as controls.
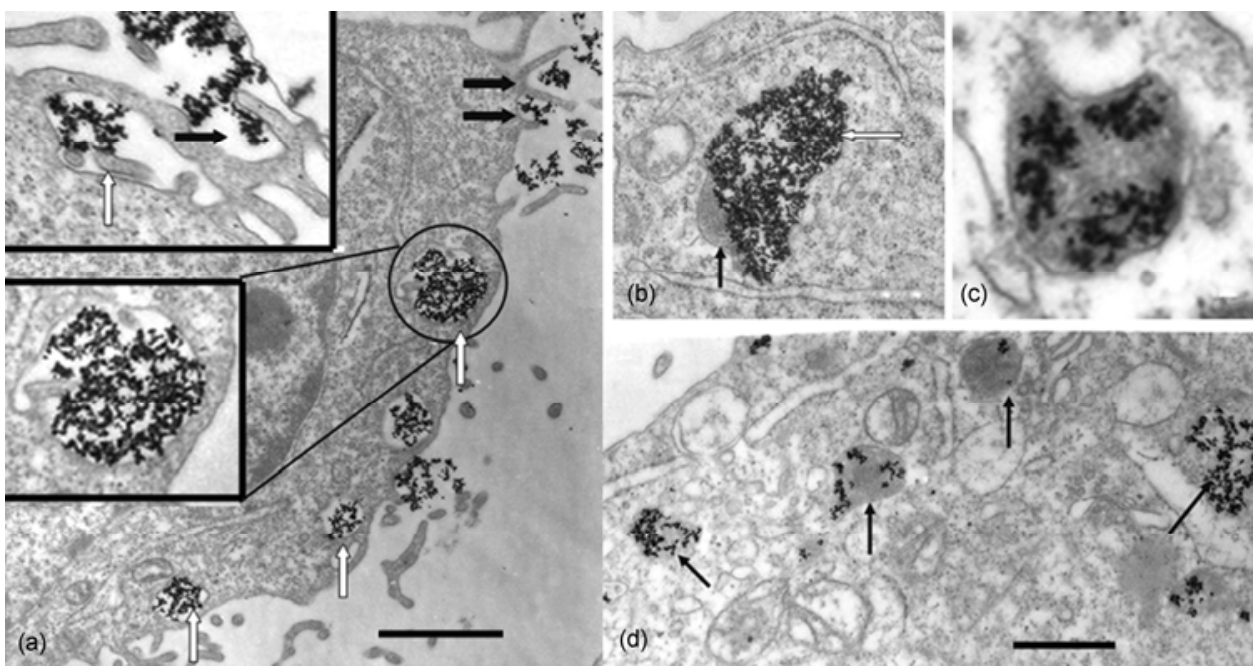

Figure 7 TEM images of the GSSG@ $\mathrm{Fe}_{3} \mathrm{O}_{4}$ uptake process into SPC-A1 cells. After co-culture of SPC-A1 cells with GSSG@ $\mathrm{Fe}_{3} \mathrm{O}_{4}$ for 1 h, GSSG@Fe $3 \mathrm{O}_{4}$ entered the coated pits ((a) black arrows) and endosomes ((a) white arrows). After $3 \mathrm{~h}$, the amalgamation process of the endosome ((b) white arrow) and the lysosome ((b) black arrow) was observed. After 6 h, many lysosomes contained entrapped GSSG@ $\mathrm{Fe}_{3} \mathrm{O}_{4}$ ((c), (d) black arrows). Scale bar=1 $\mu \mathrm{m}$.

to believe that these TEM images may show the process of pinocytosis, but further research is required for clear elucidation of this process. As in our previous research on uptake mechanisms, phagocytosis, instead of pinocytosis, may be involved in the internalization process of aminosilane-coated MNPs into SPC-A1 cells [26]. Our results showed the mechanism of endocytosis was dependent on the surface modification of nanoparticles.

\section{Conclusions}

In summary, GSSG $@ \mathrm{Fe}_{3} \mathrm{O}_{4}$ showed high biocompatibility and high capture efficiency (up to $160 \mathrm{pg}$ iron per cell) in SPC-A1 cells. Furthermore, GSSG $@ \mathrm{Fe}_{3} \mathrm{O}_{4}$ nanoparticles were retained in the cytoplasm of SPC-A1 for six generations. The uptake of GSSG@ $\mathrm{Fe}_{3} \mathrm{O}_{4}$ into SPC-A1 cells was energy, concentration and time-dependent. Pinocytosis might be involved in the internalization process of GSSG@ $\mathrm{Fe}_{3} \mathrm{O}_{4}$, but remains to be elucidated.

The safe and efficient localization of GSSG@ $\mathrm{Fe}_{3} \mathrm{O}_{4}$ to the cytoplasm may be critical in applications such as MRI, drug delivery systems for lung cancer therapy and intracellular hyperthermia. This study provides theoretical and experimental insight into the biomedical applications of GSSG@ $\mathrm{Fe}_{3} \mathrm{O}_{4}$.

The authors would like to thank the Instrumental Analysis Center of Shanghai Jiaotong University for the characterization of materials. This work was supported by the International Cooperation Project (20080068 and 075207012) and the National Natural Science Foundation of China (81000656).

1 Kumar C S S R, Mohammad F. Magnetic nanomaterials for hyper- 
thermia-based therapy and controlled drug delivery. Adv Drug Deliv Rev, 2011, 63: 789-808

2 Mykhaylyk O, Zelphati O, Hammerschmid E, et al. Recent advances in magnetofection and its potential to deliver siRNAs in vitro. Methods Mol Biol, 2009, 487: 111-146

3 Zheng Y, Tong C, Wang B, et al. Development and application of tumor-targeting magnetic nanoparticles FA-StNP@ $\mathrm{Fe}_{2} \mathrm{O}_{3}$ for hyperthermia. Chin Sci Bull, 2009, 17: 2998-3004

4 Ma Y, Zhang Z, Wang X, et al. Insights into the mechanism of magnetofection using MNPs-PEI/pDNA/free PEI magnetofectins. Int J Pharm, 2011, 419: 247-254

5 Prijic S, Sersa G. Magnetic nanoparticles as targeted delivery systems in oncology. Radiol Oncol, 2011, 45: 1-16

6 Kobayashi T. Cancer hyperthermia using magnetic nanoparticles. Biotech J, 2011, 6: 1342-1347

7 Kami D, Takeda S, Itakura Y, et al. Application of magnetic nanoparticles to gene delivery. Int J Mol Sci, 2011, 12: 3705-3722

8 Bae K H, Chung H J, Park T G. Nanomaterials for cancer therapy and imaging. Mol Cells, 2011, 31: 1-8

9 Wu X Y, Zhang J F, Lin B Y, et al. Molecular imaging of tumor angiogenesis using RGD-labeled iron oxide nanoparticles. Chin Sci Bull, 2010, 55: 2662-2670

10 Connor E, Mwamuka J, Gole A, et al. Gold nanoparticles are taken up by human cells but do not cause acute cytotoxicity. Small, 2005, 1: 325-327

11 Verma A, Stellacci F. Effect of surface properties on nanoparticlecell interactions. Small, 2009, 6: 12-21

12 Jordan A, Scholz R, Wust P, et al. Endocytosis of dextran and silan-coated magnetite nanoparticles and the effect of intracellular hyperthermia on human mammary carcinoma cells in vitro. J Magn Magn Mater, 1999, 194: 185-196

13 Harush-Frenkel O, Altsckuler Y, Benita S. Nanoparticle-cell interactions: Drug delivery implications. Crit Rev Ther Drug Carrier Syst, 2008, 25: 485-544

14 Gupta A, Gupta M. Cytotoxicity suppression and cellular uptake enhancement of surface modified magnetic nanoparticles. Biomaterials, 2005, 26: 1565-1573
15 Martin A, Bernas L, Rutt B, et al. Enhanced cell uptake of superparamagnetic iron oxide nanoparticles functionalized with dendritic guanidines. Bioconjugate Chem, 2008, 19: 2375-2384

16 Debbage P, Jaschke W. Molecular imaging with nanoparticles: Giant roles for dwarf actors. Histochem Cell Biol, 2008, 130: 845-875

17 Jolivet J, Chanéac C, Tronc E. Iron oxide chemistry. From molecular clusters to extended solid networks. Chem Commun (Camb), 2004, 2004: 481-487

18 Zhang Y, Zhang J. Surface modification of monodisperse magnetite nanoparticles for improved intracellular uptake to breast cancer cells. J Colloid Interface Sci, 2005, 283: 352-357

19 Ramge P, Unger R, Oltrogge J, et al. Polysorbate-80 coating enhances uptake of polybutylcyanoacrylate (PBCA)-nanoparticles by human and bovine primary brain capillary endothelial cells. Eur J Neurosci, 2000, 12: 1931-1940

20 Douglas K L, Piccirillo C A, Tabrizian M. Cell line-dependent internalization pathways and intracellular trafficking determine transfection efficiency of nanoparticle vectors. Eur J Pharm Biopharm, 2008, 68: 676-687

21 Shinkai M, Yanase M, Suzuki M. Intracellular hyperthermia for cancer using magnetite cationic liposomes. J Magn Magn Mater, 1999, 194: 176-184

22 Jordan A, Wust P, Scholz R, et al. Cellular uptake of magnetic fluid particles and their effects on human adenocarcinoma cells exposed to AC magnetic fields in vitro. Int J Hyperthermia, 1996, 12: 705-722

23 Wilhelm C, Billotey C, Roger J, et al. Intracellular uptake of anionic superparamagnetic nanoparticles as a function of their surface coating. Biomaterials, 2003, 24: 1001-1011

24 Petri-Fink A, Chastellain M, Juillerat-Jeanneret L, et al. Development of functionalized superparamagnetic iron oxide nanoparticles for interaction with human cancer cells. Biomaterials, 2005, 26: 2685-2694

25 Soldati T, Schliwa M. Powering membrane traffic in endocytosis and recycling. Nat Rev Mol Cell Biol, 2006, 7: 897-908

$26 \mathrm{Ma} \mathrm{Y,} \mathrm{Gu} \mathrm{H.} \mathrm{Study} \mathrm{on} \mathrm{the} \mathrm{endocytosis} \mathrm{and} \mathrm{the} \mathrm{internalization} \mathrm{mech-}$ anism of aminosilane-coated $\mathrm{Fe}_{3} \mathrm{O}_{4}$ nanoparticles in vitro. J Mater Sci Mater Med, 2007, 18: 2145-2149

Open Access This article is distributed under the terms of the Creative Commons Attribution License which permits any use, distribution, and reproduction in any medium, provided the original author(s) and source are credited. 